\title{
Semi-mandatory Dividend Policy and Investment Efficiency: Evidence from Listed Companies in China
}

\author{
Bolin Liu' ${ }^{1}$
}

\begin{abstract}
Using the new regulatory policy in 2008 as a natural experiment, this paper examines the impact of Semi-mandatory Dividend Policy (hereinafter referred to as the policy) on investment efficiency. It shows that the policy significantly improves the investment efficiency of the experimental group. The improvement effect of the policy is realized by alleviating the agency problem and increasing the stock liquidity. Further study finds that the policy significantly reduces the investmentcash flow sensitivity and increases the cash-cash flow sensitivity of the experimental group. Affected by the policy, companies implement relatively conservative investment decisions and active liquidity management decisions. However, in companies with poor accounting information quality or strong refinancing demand, the effect of improvement on investment efficiency is weakened.
\end{abstract}

JEL classification numbers: K22, G35, G38.

Keywords: Semi-mandatory Dividend Policy, Investment Efficiency, Cash Flow.

${ }^{1}$ School of Finance, Central University of Finance and Economics, China. 


\section{Introduction}

In the capital market, cash dividend, as an important way for listed companies to distribute operating profits, is of great significance to improve the capital market system and achieve high-quality development. However, since the establishment of China's securities market in the 1990s, cash dividend payment of listed company is always in a poor level ( $\mathrm{Li}, 1999$ ), which has seriously injured the interests of shareholders. In order to regulate the dividend behavior of listed company, the China Securities Regulatory Commission (CSRC) has gradually issued a series of dividend policies since 2001, which are called Semi-mandatory Dividend Policy. Different from the mandatory dividend policy in Brazil and other countries, the semi-mandatory dividend policy relates the refinancing qualification of listed companies with the cash dividend distribution level. Although the cash dividend distribution is non-forced, the semi-mandatory dividend policy can generate distribution incentives on listed companies with refinancing needs.

From the existing literature, the semi-mandatory dividend policy has made a great improvement. But the negative impact caused by the strong supervision should not be ignored. It has been found that the semi-mandatory dividend policy significantly improves the cash dividend payment of listed companies (Wei et al., 2014; Wei et al., 2017). Further study shows that the semi-mandatory dividend policy effectively reduces the equity financing cost of the affected listed companies. The effect of reduction is stronger in companies with high agency cost (Wang and Guo, 2021). In addition, the semi-mandatory dividend policy enhances investors' shareholding confidence and willingness by improving the stability of cash dividend, which improves the liquidity of stocks ( $\mathrm{Li}$ et al., 2014). From the perspective of policy supervision cost, the semi-mandatory dividend policy limits the form of dividend to cash dividend, which significantly lessens the financial flexibility of listed companies and drives up the refinance threshold of high growth companies (Wang and Zhang, 2012). What's more, it is found that the semi-mandatory dividend policy doesn't made listed companies with abundant cash flow distribute more cash dividend, but generates great "negative incentive" for high cash distribution companies, which exists a certain "regulatory paradox" (Chen, 2014; Wei et al., 2014).

In corporate finance, dividend decision is essentially the result of investment decision. Semi-mandatory dividend policy not only affects the dividend decision of listed companies, but also makes the dividend decision take precedence over the investment decision, which greatly affects the investment decision. However, there is little systematic and deep research on the impact of semi-mandatory dividend policy on the investment decision. Using the natural experimental opportunity provided by the regulatory policy in 2008 , this paper examines the economic effect of the policy on corporate investment decision. This paper takes Chinese listed company from 2006 to 2009 as the research sample. The listed company affected by the policy is divided into experimental group and the other is divided into control group. It uses the Differences-in-Differences model to examine the effect of the 
policy, which eliminates the time fixed effect and the individual fixed effect that does not change with time. In order to verify the appropriateness of the DID model, this paper uses the event study to test the parallel trend between the experimental group and the control group. The result shows that the DID model meets the parallel trend hypothesis.

It is found that Semi-mandatory dividend policy significantly improves the investment efficiency of the experimental group. The improvement effect of the policy is realized by alleviating the agency problem and increasing the stock liquidity. The effect of improvement is stronger in private corporation than in stateowned corporation. Further study finds that the policy significantly reduces the investment-cash flow sensitivity and improves the cash-cash flow sensitivity of the experimental group. Affected by the policy, companies implement relatively conservative investment decisions and active liquidity management decisions. However, in companies with poor accounting information quality or strong refinancing demand, the effect of improvement on investment efficiency is weakened.

The main contributions of the paper are as follows: (1) It examines the impact of the semi-mandatory dividend policy on corporate investment decision, which helps us evaluate the economic effect of the semi-mandatory dividend policy objectively. (2) It is a useful supplement to the research on investment efficiency. The study on investment efficiency mainly focuses on agency cost, media attention and so on. There is little literature about the impact of dividend policy on investment efficiency. (3) The conclusion of this paper is of enlightenment significance for the high-quality development of capital market. The paper provides reference for the improvement of the policy.

\section{Literature Review}

The dividend agency theory holds that the payment of cash dividend by listed company can effectively inhibit managers from abusing corporate cash flow, reducing inefficient investment and lessening the agency costs (Easterbrook, 1984). In the western mature capital market, the relatively orderly corporate governance system and sound legal system make a great contribution to the protection of shareholders' rights and interests. When lack of good investment opportunity, the corporate governance system will force listed companies to pay the cash dividends, in order to inhibit the inefficient investment. However, in developing countries, the corporate governance system is inefficient (Shleifer and Vishny, 1997). The law for the protection of investors' rights and interests are also not sound. So it is difficult to force listed companies to pay the cash dividends actively. Porta et al. (2000) believe that the regulators can promote the cash dividend of listed companies through mandatory dividend policy. The mandatory dividend policy makes rules on the profit distribution and the form of dividend. The countries such as Brazil, Chile and Colombia have issued mandatory dividend policies and make a great success (Martins and Novaes, 2012). 
Since the establishment of China's securities market in the 1990s, cash dividend payment of listed company is always in a poor level (Li, 1999). In order to standardize the dividend payment of listed company, the China Securities Regulatory Commission (CSRC) have gradually issued a series of dividend regulatory policies, which are called Semi-mandatory dividend policy. In 2008, the CSRC required that the accumulated cash dividend in the past three years must reach a certain proportion if the company wants to refinance. At the same time, listed companies are required to disclose the decision-making and implementation process related to dividends.

Since the implementation of the semi-mandatory dividend policy, its effectiveness and rationality are always the focus of academic discussion. From the perspective of the governance effect, it has been found that the semi-mandatory dividend policy significantly improves the cash dividend payment of listed companies (Wei et al., 2014). In addition, cash dividend can effectively reduce the agency cost of listed companies, which inhibits inefficient investment caused by agency problems. Therefore, we believe that the semi-mandatory dividend policy can improve the investment efficiency by alleviating the agency problems of listed company. Further research shows that the semi-mandatory dividend policy greatly enhances investors' shareholding confidence and willingness, improving the liquidity level of stocks ( $\mathrm{Li}$ et al., 2014). The improvement of stock liquidity increases the information efficiency of stock price, helps to restrain inefficient investment and thus improves the investment efficiency of listed companies (Xiong and $\mathrm{Su}, 2014$ ). Based on the above analysis, we propose hypothesis H1: The semi-mandatory dividend policy improves the investment efficiency of the listed company.

From the perspective of the cost of strong policy supervision, there may be "regulatory paradox" in the semi-mandatory dividend policy. Chen (2014) found that the semi-mandatory dividend policy doesn't make the listed company with abundant cash flow pay more cash dividend. Wang and Zhang (2012) believe that the semi-mandatory dividend policy significantly reduces the financial flexibility of listed company. Welker et al. (2017) found that the semi-mandatory dividend policy urges listed companies to strengthen earnings management, and the company may reduce dividend payment by manipulating accruals downward.

\section{Model and data}

\subsection{Investment efficiency measurement}

Based on the research of Richardson (2006) and Liu (2014), this paper uses the predicted investment model to estimate the investment efficiency. The specific model is as follow:

$$
\begin{gathered}
\text { Invest }_{t}=\beta_{0}+\beta_{1} \text { Growth }_{t-1}+\beta_{2} \text { Lev }_{t-1}+\beta_{3} \text { Cash }_{t-1}+\beta_{4} \text { Age }_{t-1}+\beta_{5} \text { Size }_{t-1} \\
+\beta_{6} \text { Return }_{t-1}+\beta_{7} \text { Invest }_{t-1}+\varepsilon_{t}
\end{gathered}
$$

Where Invest $_{t}$ is the new investment of the company in the $t$ year, Growth $h_{t-1}$, 
$L e v_{t-1}, \operatorname{Cash}_{t-1}, A g e_{t-1}, \operatorname{Size}_{t-1}$, Return $_{t-1}$ are the growth rate of operating income, debt asset ratio, cash and cash equivalents divided by total asset, natural logarithm of listing years, natural logarithm of total assets and annual stock return in the $t+1$ year. Model (1) also controls the annual fixed effect and industry fixed effect. The absolute value of the residual estimated by model (1) is the $E C A_{i t}$ which measures the investment efficiency of listed company. The greater the value, the higher the inefficient investment degree and the lower the investment efficiency.

\subsection{Regression model setup}

In order to examine the impact of semi-mandatory dividend policy on the investment efficiency of listed company, the paper uses the OLS and DID model to estimate the effect of the policy. The regression model can be set as following:

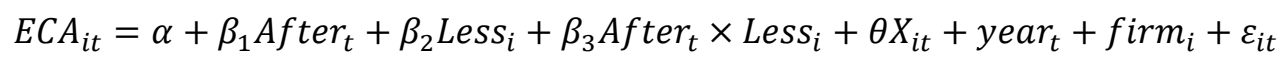

Where $E C A_{i t}$ is the investment efficiency of the listed company. After th $_{t}$ is the policy promulgation period, which is 0 before promulgation and 1 after promulgation. Less $i$ is whether the company is affected by the policy. If the accumulated cash dividend before the promulgation of the policy is less than $30 \%$ of the average annual distributable profit realized in the last three years, the value is 1 , otherwise it is $0 . X_{i t}$ is the control variable, referring to the design of Richardson (2006), Liu et al. (2014) and Yao et al. (2020). The definition of each variable is listed in Table 1.

Table 1: Control variable

\begin{tabular}{|c|c|}
\hline Control variable & Variable description \\
\hline Growth & growth rate of operating income \\
\hline Income & natural logarithm of operating income \\
\hline Size & natural logarithm of total assets \\
\hline Lev & debt asset ratio \\
\hline Sala & natural logarithm of management compensation \\
\hline ADM & administrative expenses / operating income \\
\hline Indboard & number of independent directors / number of directors \\
\hline Boardsize & number of directors \\
\hline Top1 & shareholding ratio of the largest shareholder \\
\hline SEO & If it is state-owned enterprise, the value is 1, otherwise it is 0. \\
\hline
\end{tabular}

\subsection{Sample selection and summary statistics}

Taking the Chinese listed company from 2006 to 2009 as the research sample, excluding the financial company and the sample with missing data, this paper finally obtains 4945 observations, and winsorize by $1 \%$ and $99 \%$. The research data comes from CSMAR database and Wind database. According to the policy in 2008, the 
refinance company should comply with the requirement that the accumulated cash dividend distributed in the last three years should not be less than $30 \%$ of the average distributable profits realized in the last three years. Different from the dividend policy in 2006 , the decision links the refinancing qualification to the cash dividend distribution, excluding stock dividend, which provides a good experimental opportunity for us to focus on the semi- mandatory cash dividend policy. In order to avoid the interference of dividend policy in 2006, we selected the samples after the implementation of dividend policy in 2006 and the samples two years after the promulgation of the policy in 2008. Table 2 shows the statistical description of key variables used in the paper.

Table 2: Statistical description

\begin{tabular}{|c|c|c|c|c|c|c|}
\hline Variables & $\mathbf{N}$ & Mean & S.D. & Min & Median & Max \\
\hline ECA & 4945 & 0.134 & 0.171 & 0.001 & 0.088 & 1.036 \\
\hline After & 4945 & 0.526 & 0.499 & 0 & 1 & 1 \\
\hline Less & 4945 & 0.458 & 0.498 & 0 & 0 & 1 \\
\hline After $\times$ Less & 4945 & 0.238 & 0.426 & 0 & 0 & 1 \\
\hline Growth & 4945 & 0.191 & 0.544 & -0.767 & 0.113 & 3.547 \\
\hline Income & 4945 & 11.730 & 1.477 & 7.237 & 11.720 & 15.450 \\
\hline Size & 4945 & 21.520 & 1.176 & 18.700 & 21.440 & 24.990 \\
\hline Lev & 4945 & 0.546 & 0.279 & 0.082 & 0.533 & 2.190 \\
\hline Sala & 4945 & 5.242 & 0.799 & 3.319 & 5.237 & 7.264 \\
\hline ADM & 4945 & 0.102 & 0.139 & 0.008 & 0.068 & 1.109 \\
\hline Indboard & 4945 & 0.356 & 0.047 & 0.250 & 0.333 & 0.556 \\
\hline Boardsize & 4945 & 9.351 & 1.889 & 5 & 9 & 15 \\
\hline Top 1 & 4945 & 35.640 & 14.920 & 8.810 & 33.570 & 72.510 \\
\hline SEO & 4945 & 0.639 & 0.480 & 0 & 1 & 1 \\
\hline
\end{tabular}

\section{Empirical results}

\subsection{Parallel trend test}

One of the preconditions for the effectiveness of the DID model is that the experimental group and the control group have parallel trend before the policy promulgation. In order to verify the appropriateness of DID model, the paper uses the event study method to test the parallel trend between the experimental group and the control group (Wang et al., 2020). The policy promulgation year (2008) is set as the base year for event study. Compared with the base year, the parallel trend assumption requires that the investment efficiency of the experimental group and the control group is not different in trend before the policy promulgation. Figure 1 shows that before promulgation in 2008 , the trend of investment efficiency between the experimental group and the control group is not significantly different. After the promulgation, the trend of investment efficiency is significantly different. The result shows that the DID model used in this paper meets the parallel trend hypothesis. 
What's more, the result shows that the promulgation of the policy significantly improves the investment efficiency of the experimental group, which preliminarily supports hypothesis $\mathrm{H} 1$.

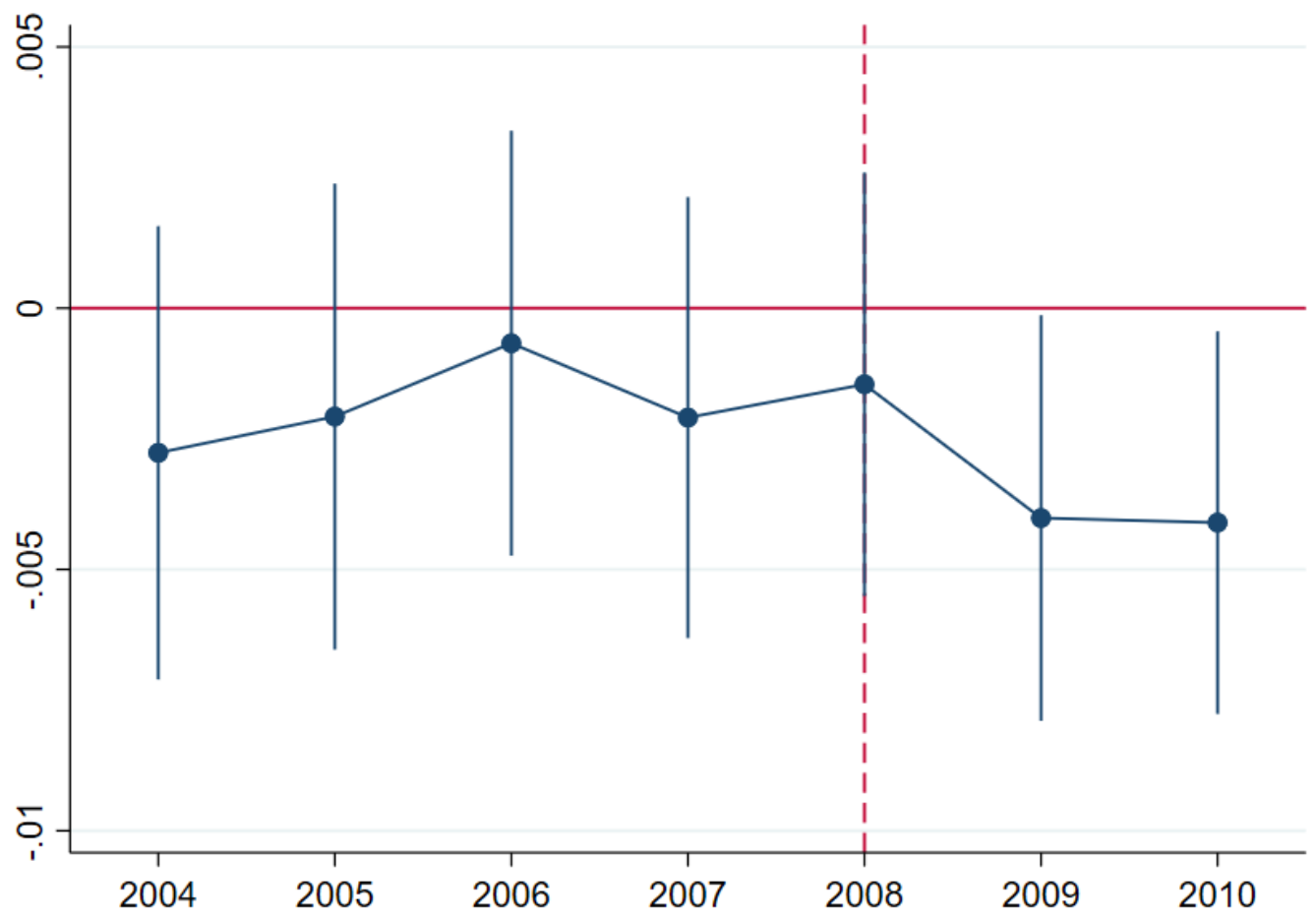

Figure 1: Parallel trend test

\subsection{Semi-mandatory dividend policy and investment efficiency}

Table 3 shows the regression result of the impact of semi-mandatory dividend policy on investment efficiency. In columns (1) - (4), the estimation results of univariate OLS, univariate OLS with industry and time fixed effects, multivariable OLS and DID model are given. The regression results show that there is a significant negative correlation between After $\times$ Less and ECA. If the ECA value is smaller, the inefficient investment of the company is lower and the investment efficiency is higher. Therefore, compared with the control group, the semimandatory dividend policy improves the investment efficiency of the experimental group, indicating that the semi-mandatory dividend policy has improvement effect on investment efficiency, supporting the hypothesis H1. 
Table 3: Semi-mandatory dividend policy and investment efficiency

\begin{tabular}{|c|c|c|c|c|}
\hline & (1) & (2) & (3) & (4) \\
\hline & $E C A$ & $E C A$ & $E C A$ & $E C A$ \\
\hline After & $\begin{array}{c}-0.0152^{\text {*** }} \\
(-2.40)\end{array}$ & & & \\
\hline Less & $\begin{array}{c}0.0380^{* * * *} \\
(5.33)\end{array}$ & $\begin{array}{c}0.0382^{* * *} \\
(9.89)\end{array}$ & $\begin{array}{c}0.0193^{* * *} \\
(5.33)\end{array}$ & \\
\hline After $\times$ Less & $\begin{array}{c}-0.0230^{* * *} \\
(-2.35)\end{array}$ & $\begin{array}{c}-0.0218^{* * * *} \\
(-4.18)\end{array}$ & $\begin{array}{c}-0.0225^{* * *} \\
(-4.65)\end{array}$ & $\begin{array}{c}-0.0160^{* * * *} \\
(-3.61)\end{array}$ \\
\hline Growth & & & $\begin{array}{c}0.0112^{* * * *} \\
(3.98)\end{array}$ & $\begin{array}{c}-0.0121^{\text {**** }} \\
(-4.57)\end{array}$ \\
\hline Income & & & $\begin{array}{c}-0.0032 \\
(-1.31)\end{array}$ & $\begin{array}{c}0.0156^{* * * *} \\
(2.94)\end{array}$ \\
\hline Size & & & $\begin{array}{c}-0.0070^{* * * *} \\
(-2.71)\end{array}$ & $\begin{array}{l}0.0056 \\
(1.08)\end{array}$ \\
\hline Lev & & & $\begin{array}{c}0.0766^{\text {**** }} \\
(9.84)\end{array}$ & $\begin{array}{c}0.0508^{* * * *} \\
(4.59)\end{array}$ \\
\hline Sala & & & $\begin{array}{c}0.0037^{*} \\
(1.92)\end{array}$ & $\begin{array}{c}0.0026 \\
(0.62)\end{array}$ \\
\hline$A D M$ & & & $\begin{array}{c}0.0877^{* * * *} \\
(4.87)\end{array}$ & $\begin{array}{c}0.0781^{* * * *} \\
(3.89)\end{array}$ \\
\hline Indboard & & & $\begin{array}{c}-0.0037 \\
(-0.14)\end{array}$ & $\begin{array}{c}-0.0685 \\
(-1.64)\end{array}$ \\
\hline Boardsize & & & $\begin{array}{c}0.0004 \\
(0.50) \\
\end{array}$ & $\begin{array}{c}-0.0001 \\
(-0.07) \\
\end{array}$ \\
\hline Top 1 & & & $\begin{array}{c}0.0007^{* * *} \\
(7.35)\end{array}$ & $\begin{array}{c}0.0007^{* * * *} \\
(2.65)\end{array}$ \\
\hline SEO & & & $\begin{array}{c}-0.0164^{* * * *} \\
(-6.05)\end{array}$ & \\
\hline Constant & $\begin{array}{c}0.1300^{* * * *} \\
(28.11)\end{array}$ & $\begin{array}{c}0.9400^{* * *} \\
(96.26)\end{array}$ & $\begin{array}{c}1.0470^{* * * *} \\
(27.41)\end{array}$ & $\begin{array}{c}-0.1670^{*} \\
(-1.80)\end{array}$ \\
\hline firm & & & & yes \\
\hline industry & & yes & yes & \\
\hline year & & yes & yes & yes \\
\hline Observations & 4945 & 4945 & 4945 & 4945 \\
\hline$R-$ Squared & 0.013 & 0.729 & 0.760 & 0.156 \\
\hline
\end{tabular}

Notes: Significance at $1 \%, 5 \%$, and $10 \%$ level is indicated by ${ }^{* * *},{ }^{* *},{ }^{*}$, respectively. 


\subsection{Robustness}

\subsubsection{Placebo test}

In order to examine whether the improvement effect of semi-mandatory dividend policy on investment efficiency is driven by some unknown random factors, this paper uses the way of Liu et al. (2020) for placebo test. We randomly generate the experimental group from the whole sample according to the original proportion and regress according to the setting of model (2). We obtain the t-statistic of the corresponding interaction term After $\times$ Less. Repeat above steps 10000 times, and plot the t-statistic in Figure 2. The figure shows that the t-statistics of the interaction term obtained from 10000 experiments are normally distributed centered on 0 , and their absolute values are less than the absolute value of the t-statistics (4.65) obtained from real data. Therefore, it can be considered that the improvement effect of semi-mandatory dividend policy on investment efficiency is not caused by random factors.

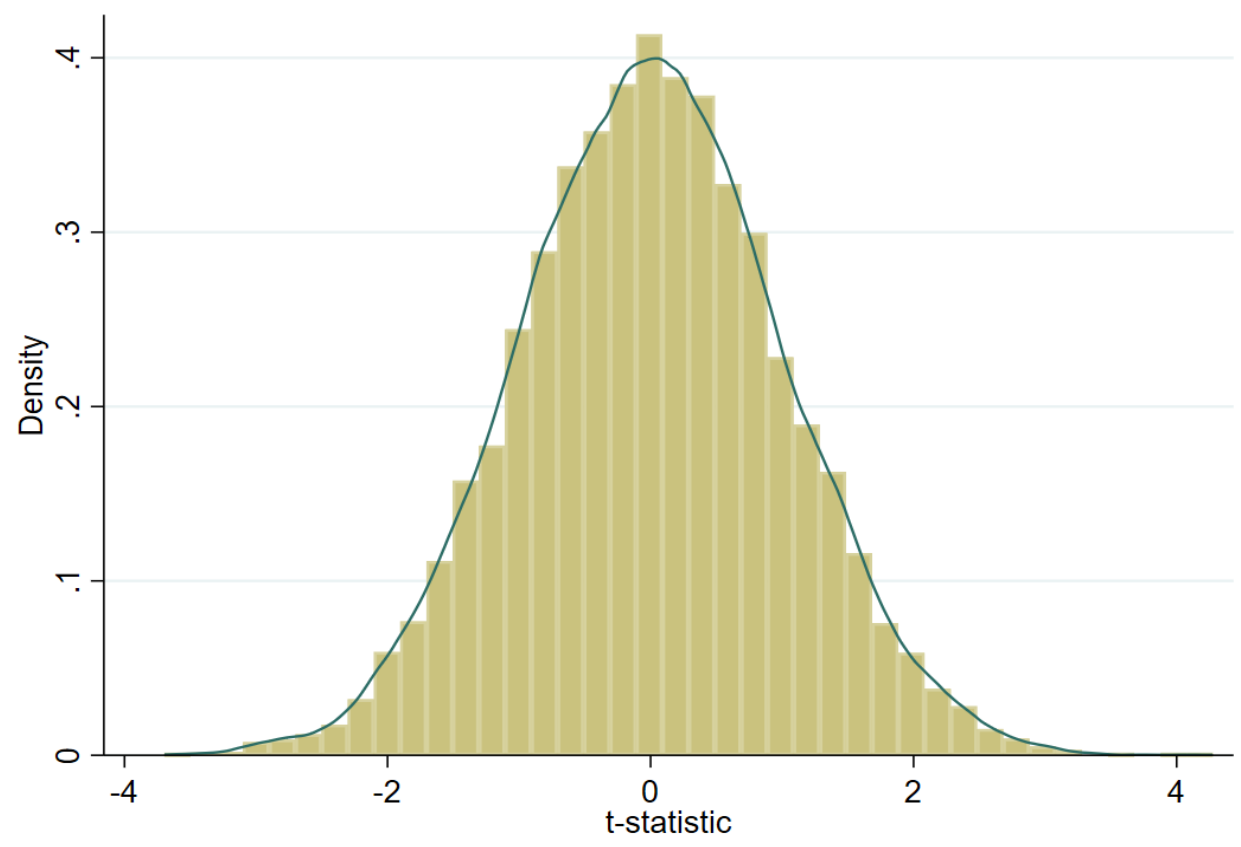

Figure 2: Placebo test

\subsubsection{Replace sample interval}

In order to eliminate the interference of abnormal samples, this paper refers to the research of $\mathrm{Lu}$ et al. (2010) and excludes listed companies with radical dividend policy (i.e. cash dividend payout ratio exceeding 1). The columns (1) - (2) of table 4 show that After $\times$ Less has a negative correlation with ECA, which is significant at the $1 \%$ level. The conclusion of the paper is robust. Considering the noise of the sample in 2008 when the policy was promulgated, this paper eliminates the sample in 2008 and expands the sample to 2010. Column (3) of table 4 shows that the interaction term coefficient is significantly negative at the level of $1 \%$. In 
addition, we expand the sample interval from 2005 to 2011. Column (4) of table 4 shows that the interactive term coefficient is significantly negative at the level of $5 \%$. The conclusion of the paper is robust.

Table 4: Semi-mandatory dividend policy and investment efficiency

\begin{tabular}{|c|c|c|c|c|}
\hline & $\begin{array}{c}(\mathbf{1}) \\
\text { OLS }\end{array}$ & $\begin{array}{c}(\mathbf{F}) \\
\text { Less }\end{array}$ & $\begin{array}{c}\mathbf{( 3 )} \\
\mathbf{F E} \\
\mathbf{2 0 0 6 - 2 0 1 0}\end{array}$ & $\begin{array}{c}\mathbf{( 4 )} \\
\mathbf{F E} \\
\mathbf{2 0 0 5 - 2 0 1 1}\end{array}$ \\
\hline After $\times$ Less & $\begin{array}{c}-0.0175^{* * *} \\
(-3.34)\end{array}$ & $\begin{array}{c}-0.0151^{* * * *} \\
(-3.01)\end{array}$ & $\begin{array}{c}-0.0121^{* * *} \\
(-3.03)\end{array}$ & $\begin{array}{c}-0.0054^{* *} \\
(-1.98)\end{array}$ \\
\hline firm & & yes & yes & yes \\
\hline industry & yes & & & \\
\hline control & yes & yes & yes & yes \\
\hline year & yes & yes & yes & yes \\
\hline Observations & 4198 & 4198 & 5168 & 7780 \\
\hline$R-$ Squared & 0.771 & 0.147 & 0.241 & 0.328 \\
\hline
\end{tabular}

\subsubsection{Replace investment efficiency measurement}

Based on the study of Richardson (2006) and Cheng (2015), this paper uses TobinQ and the growth ratio of total asset to substitute the Growth in model (1). In this way, we estimate ECA again, and then run the model (2). Columns (1) - (2) of Table 5 show the results estimated by TobinQ , and columns (3) - (4) show the regression results estimated by the growth rate of total asset. The coefficient of After $\times$ Less is negative and significant at the level of $1 \%$. The conclusion of the paper is still robust.

Table 5: Replace investment efficiency measurement

\begin{tabular}{|c|c|c|c|c|}
\hline & $(\mathbf{1})$ & $(\mathbf{2})$ & $\mathbf{( 3 )}$ & $\mathbf{( 4 )}$ \\
\hline & $\begin{array}{c}\text { OLS } \\
\text { TobinQ }\end{array}$ & $\begin{array}{c}\boldsymbol{F E} \\
\text { TobinQ }\end{array}$ & $\begin{array}{c}\boldsymbol{O L S} \\
\text { Growth Ratio }\end{array}$ & $\begin{array}{c}\boldsymbol{F E} \\
\text { Growth Ratio }\end{array}$ \\
\hline Less & $\begin{array}{c}0.0152^{* * *} \\
(4.20)\end{array}$ & & $0.0130^{* * * *}$ & \\
& & $(3.89)$ & \\
\hline After $\times$ Less & $-0.0288^{* * *}$ & $-0.0248^{* * *}$ & $-0.0223^{* * *}$ & $-0.0186^{* * *}$ \\
& $(-6.01)$ & $(-5.80)$ & $(-5.05)$ & $(-4.57)$ \\
\hline firm & & yes & & yes \\
\hline industry & yes & & yes & yes \\
\hline control & yes & yes & yes & yes \\
\hline year & yes & yes & yes & 4949 \\
\hline Observations & 4848 & 4848 & 4949 & 0.191 \\
\hline$R-$ Squared & 0.779 & 0.169 & 0.793 & \\
\hline
\end{tabular}




\section{Mechanism}

The semi-mandatory dividend policy significantly improves the investment efficiency of the listed company. We believe that the improvement effect of the policy is realized by alleviating the agency problem and increasing the stock liquidity. In this section, the paper will empirically examine above mechanism.

\subsection{Semi-mandatory dividend policy, agency cost and investment efficiency}

We believe that the semi-mandatory dividend policy can effectively reduce the agency cost of listed company by promoting the cash dividend payment. In order to verify the existence of the mechanism, the paper measures the agency cost by dividing other receivables by total asset $\left(A \operatorname{Cost}_{1}\right)$ and operating revenue by total asset $\left(\right.$ CCost $\left._{2}\right)$ (Luo et al., 2017). The regression model can be set as following:

$$
\text { Cost }_{i t}=\beta_{0}+\beta_{1} \text { Less }_{i}+\beta_{2} \text { After }_{t} \times \text { Less }_{i}+\theta X_{i t}+\text { year }_{t}+\text { industry }_{i}+\varepsilon_{i t}
$$

Where Cost $_{i t}$ is the agency cost and $X_{i t}$ is control variable, including $S E O_{i t}$,

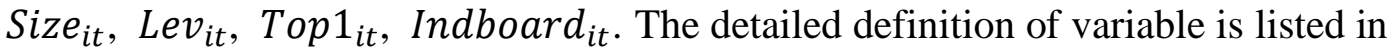
Table1. Model (3) includes the year fixed effect and industry fixed effect.

Table 6 reports the result of model (3). The dummy variable After $\times$ Less has negative correlation with $A \operatorname{Cost}_{1}$, significant at $1 \%$ level, and positive correlation with $\mathrm{ACost}_{2}$, significant at the $10 \%$ level. The result shows that compared with the control group, the semi-mandatory dividend policy significantly reduces the agency cost of the experimental group. The semi-mandatory dividend policy improves the investment efficiency by alleviating the agency problem of listed companies.

Table 6: Semi-mandatory dividend policy and agency cost

\begin{tabular}{|c|c|c|}
\hline & (1) & (2) \\
\hline & ACost $_{\mathbf{1}}$ & ACost $_{\mathbf{2}}$ \\
\hline Less & $0.0002^{\text {**** }}$ & $-0.0015^{* * *}$ \\
& $(10.25)$ & $(-6.87)$ \\
\hline After $\times$ Less & $-0.0002^{* * *}$ & $0.0005^{*}$ \\
& $(-5.45)$ & $(1.76)$ \\
\hline control & yes & yes \\
\hline year & yes & yes \\
\hline industry & yes & yes \\
\hline Observations & 4941 & 4945 \\
\hline R Squared & 0.200 & 0.195 \\
\hline
\end{tabular}

\subsection{Semi-mandatory dividend policy, stock liquidity and investment efficiency}

Xiong and $\mathrm{Su}$ (2014) found that the improvement of stock liquidity helps to alleviate the underinvestment and inhibit the overinvestment of listed company, improving the investment efficiency. This paper uses the average annual turnover rate $(F L)$ to 
measure the stock liquidity. Table 7 reports the result of the mechanism analysis of stock liquidity level. Column (1) shows the OLS regression results of FL. The explanatory variable coefficient is positive and significant at the level of $1 \%$, indicating that the semi-mandatory dividend policy improves the stock liquidity of the affected companies. Column (2) shows the regression results by the DID model. The explanatory variable coefficient is positive and significant at the level of $1 \%$, indicating that the semi-mandatory dividend policy significantly improves the stock liquidity of the affected companies, which is consistent with above analysis. The result shows that the semi-mandatory dividend policy improves the investment efficiency of the affected companies by increasing the stock liquidity. It proves that stock liquidity is one of the mechanisms of the semi-mandatory dividend policy.

Table 7: Semi-mandatory dividend policy, stock liquidity

\begin{tabular}{|c|c|c|}
\hline & $(\mathbf{1})$ & (2) \\
\hline & $\boldsymbol{F L}$ & $\boldsymbol{F L}$ \\
\hline Less & $0.0416^{* * *}$ & \\
\hline After $\times$ Less & $(7.27)$ & $0.1659^{* * *}$ \\
& $0.4022^{* * *}$ & $(2.77)$ \\
\hline control & yes & yes \\
\hline year & yes & yes \\
\hline industry & yes & \\
\hline firm & & yes \\
\hline Observations & 4927 & 4927 \\
\hline$R-$ Squared & 0.286 & 0.432 \\
\hline
\end{tabular}

\section{Additional analysis}

In this section, we will carry out additional analysis on impact of semi-mandatory dividend policy on investment decision of listed company. We will examine the economic effect of the policy from the perspective of investment-cash flow sensitivity, cash-cash flow sensitivity and policy limitation.

\subsection{Semi-mandatory dividend policy and investment-cash flow sensitivity}

Based on the study of Qu et al. (2011) and Lian et al. (2010), the regression model can be set as following:

$$
\begin{gathered}
\text { Invest }_{i t}=\beta_{0}+\beta_{1} \text { Treat }_{i t}+\beta_{2} C F_{i t}+\beta_{3} \text { Treat }_{i t} \times C F_{i t}+\beta_{4} \text { TobinQ }_{i, t-1}+\theta X_{i t}+\varepsilon_{i t} \\
\Delta \text { Cash }_{i t}=\beta_{0}+\beta_{1} \text { Treat }_{i t}+\beta_{2} C F_{i t}+\beta_{3} \text { Treat }_{i t} \times C F_{i t}+\theta X_{i t}+\varepsilon_{i t}
\end{gathered}
$$

Model (4) is used to examine the impact of semi-mandatory dividend policy on investment-cash flow sensitivity. $\beta_{2}$ measures the investment-cash flow sensitivity 
of the control group. $\beta_{2}+\beta_{3}$ measures the investment-cash flow sensitivity of the experimental group. Invest ${ }_{i t}$ is the new investment of listed company. Treat $t_{i t}$ is dummy variable of the experimental group. $C F_{i t}$ is the net cash flow generated by operating activities divided by the total asset. $X_{i t}$ is control variable, including $S E O_{i t}$, Growth $_{i, t-1}, \operatorname{Lev}_{i, t-1}, \mathrm{Cash}_{i, t-1}$. The detailed definition of variables are listed in Table 1. Model (3) control the year fixed effect and industry fixed effect. Model (5) is used to examine the impact of semi-mandatory dividend policy on cash-cash flow sensitivity. $\beta_{2}$ measures the cash-cash flow sensitivity of the control group, $\beta_{2}+\beta_{3}$ measures the cash-cash flow sensitivity of the experimental group. $\Delta$ Cash $_{i t}$ is the change of cash holdings of listed company. $X_{i t}$ is control variable, including the growth ratio of operating income, the natural logarithm of total asset, the change of short-term loan and new investment.

Model (5) also controls the year fixed effect and industry fixed effect.

Column (1) of table 8 reports the result of model (4), and the coefficient $\beta_{2}$ is positive and significant at the $1 \%$ level. The coefficient $\beta_{3}$ of Treat $\times C F$ is negative and significant at the $1 \%$ level. The result shows that compared with the control group, the semi-mandatory dividend policy significantly reduces the investment-cash flow sensitivity of the experimental group, and the listed companies tend to be conservative in investment under the influence of the policy. Column (2) of table 8 reports the result of model (5). The coefficient $\beta_{3}$ of Treat $\times C F$ is positive and significant at the 5\% level. The result shows that compared with the control group, the semi-mandatory dividend policy significantly increases the cash-cash flow sensitivity of the experimental group, and the companies tend to high liquidity under the influence of the policy. Based on the above analysis, we believe that the semi-mandatory dividend policy inhibits the investment behavior of listed company and promotes the company to implement more active liquidity management, and be conservative in financial decision. 
Table 8: Semi-mandatory dividend policy and investment-cash flow sensitivity

\begin{tabular}{|c|c|c|}
\hline & $(\mathbf{1})$ & $(\mathbf{2})$ \\
\hline & Invest & DCash \\
\hline Treat & $-0.0092^{* * *}$ & 0.0053 \\
& $(-4.38)$ & $(1.46)$ \\
\hline CF & $0.0274^{* * *}$ & 0.0084 \\
& $(8.59)$ & $(0.95)$ \\
\hline Treat $\times$ CF & $-0.0112^{* * *}$ & $0.1190^{* *}$ \\
& $(-2.85)$ & $(2.40)$ \\
\hline TobinQ & $-0.0018^{* * *}$ & \\
\hline control & $(-3.04)$ & yes \\
\hline year & yes & yes \\
\hline industry & yes & yes \\
\hline Observations & yes & 4937 \\
\hline$R-$ Squared & 4773 & 0.0465 \\
\hline
\end{tabular}

\subsection{Semi-mandatory dividend policy, accounting quality and investment efficiency}

Wang and Guo (2021) found that the semi-mandatory dividend policy helps to reduce the financing cost of listed companies with good accounting information quality, but its improvement effect is weakened for listed companies with poor accounting information quality. This paper uses earnings aggressiveness $(E a)$ and earnings smoothing (Es) as proxy variable of accounting information quality to examine the effect of semi-mandatory dividend policy (you and Li, 2007). Earnings aggressiveness and earnings smoothness represent the degree of whitewashing of financial statement. The greater it is, the lower the accounting quality is. This paper uses the median of $E a$ and $E s$ to divide the samples into good accounting quality group and poor accounting quality group. The regression results of $E a$ and $E s$ in Table 9 show that the coefficient of After $\times$ Less in the good accounting quality group is negative and significant at the level of $1 \%$. However, the coefficient in the low accounting quality group is not related to investment efficiency. The coefficient comparison test between groups is significant at the level of 5\%, which shows that compared with companies with poor accounting information quality, semimandatory dividend policy is more likely to improve the investment efficiency of companies with good accounting information quality. For companies with poor accounting information quality, the improvement effect of semi-mandatory dividend policy is weakened. 
Table 9: Semi-mandatory dividend policy, accounting quality and investment efficiency

\begin{tabular}{|c|c|c|c|c|c|c|}
\hline & (1) & (2) & (3) & (4) & (5) & (6) \\
\hline & $\begin{array}{c}E a \\
\text { Good }\end{array}$ & $\begin{array}{c}E a \\
\text { Poor }\end{array}$ & $\begin{array}{c}E a \\
\text { Comparison }\end{array}$ & $\begin{array}{c}E s \\
\text { Good }\end{array}$ & $\begin{array}{c}E S \\
\text { Poor }\end{array}$ & $\begin{array}{c}E S \\
\text { Comparison }\end{array}$ \\
\hline Less & $\begin{array}{c}0.0200^{* * *} \\
(3.78)\end{array}$ & $\begin{array}{c}0.0111^{* *} \\
(2.01)\end{array}$ & 0.009 & $\begin{array}{c}0.0212^{* * *} \\
(3.70)\end{array}$ & $\begin{array}{c}0.0118^{* *} \\
(2.19)\end{array}$ & 0.009 \\
\hline After $\times$ Less & $\begin{array}{c}-0.0242^{* * * *} \\
(-3.62)\end{array}$ & $\begin{array}{c}-0.0054 \\
(-0.73) \\
\end{array}$ & $-0.019^{* *}$ & $\begin{array}{c}-0.0247^{* * * *} \\
(-3.53)\end{array}$ & $\begin{array}{c}-0.0071 \\
(-0.99) \\
\end{array}$ & $-0.018^{* *}$ \\
\hline control & yes & yes & yes & yes & yes & yes \\
\hline year & yes & yes & yes & yes & yes & yes \\
\hline industry & yes & yes & yes & yes & yes & yes \\
\hline Observations & 1705 & 1706 & & 1706 & 1705 & \\
\hline$R-$ Squared & 0.851 & 0.757 & & 0.828 & 0.786 & \\
\hline
\end{tabular}

Notes: the coefficient comparison is used to examine the significance of the difference of coefficient between groups. The result is obtained by Fisher test through 1000 bootstrap times.

\subsection{Semi-mandatory dividend policy, refinancing demand and investment efficiency}

Wang and Zhang (2012) believe that the semi-mandatory dividend policy significantly reduces the financial flexibility of listed companies with high refinancing demand and makes great negative impact on them. Based on the study of Lu and Zhang (2014), this paper takes the difference between enterprise growth and achievable endogenous growth as the refinancing demand $(F N)$. We use the median of $F N$ to divide the samples into high refinancing demand group and low refinancing demand group. Table 10 shows that the coefficient of After $\times$ Less in low refinancing demand group is negative and significant at the level of $1 \%$. However, the coefficient in high refinancing demand group is not related to investment efficiency. The coefficient comparison test between groups is significant at the level of $1 \%$, which shows that compared with companies with high refinancing demand, semi-mandatory dividend policy is more likely to improve the investment efficiency of companies with low refinancing demand. 
Table 10: Semi-mandatory dividend policy, refinancing demand and investment efficiency

\begin{tabular}{|c|c|c|c|}
\hline & $(\mathbf{1})$ & $(\mathbf{2})$ & $\mathbf{( 3 )}$ \\
\hline & Low & High & Comparison \\
\hline Less & $0.0210^{* * *}$ & $0.0167^{* * *}$ & 0.004 \\
& $(4.46)$ & $(2.84)$ & \\
\hline After $\times$ Less & $-0.0291^{* * *}$ & -0.0086 & $-0.020^{* * *}$ \\
& $(-4.56)$ & $(-1.07)$ & \\
\hline control & yes & yes & yes \\
\hline year & yes & yes & yes \\
\hline industry & yes & yes & yes \\
\hline Observations & 2469 & 2476 & \\
\hline$R-$ Squared & 0.779 & 0.766 & \\
\hline
\end{tabular}

Notes: the coefficient comparison is used to examine the significance of the difference of coefficient between groups. The result is obtained by Fisher test through 1000 bootstrap times.

\section{Conclusion}

Using the natural experimental opportunity provided by the regulatory policy in 2008, this paper examines the economic effect of the policy on corporate investment decision. This paper takes Chinese listed company from 2006 to 2009 as the research sample. It is found that semi-mandatory dividend policy significantly improves the investment efficiency of the experimental group. The improvement effect of the policy is realized by alleviating the agency problem and increasing the stock liquidity. The effect of improvement is stronger in private corporation than in state-owned corporation. Further study finds that the policy significantly reduces the investment-cash flow sensitivity and improves the cash-cash flow sensitivity of the experimental group. Affected by the policy, companies implement relatively conservative investment decisions and active liquidity management decisions. However, in companies with poor accounting information quality or strong refinancing demand, the effect of improvement on investment efficiency is weakened. The paper helps us evaluate the effect of the semi-mandatory dividend policy objectively. It is a useful supplement to the research on investment efficiency. The conclusion of the paper is of enlightenment significance for the high-quality development of capital market and help the government formulate dividend policy. 


\section{References}

[1] Chen, Y. (2014). A Study on the Impacts of the Semi-mandatory Dividend Policy. Journal of Finance Research, 08, 162-177.

[2] Cheng, X., Liu, J. and Wang, Z. (2015). Can Media Coverage Improve Corporate Investment Efficiency? Collected Essays on Finance and Economics, 04, 45-52.

[3] Easterbrook, F.E. (1984). Two Agency-Cost Explanations of Dividends. The American Economic Review, 74(4), 650-659.

[4] Li, C. (1999). Current Situation and Causes of Dividend Policy of Listed Companies in China. China Industrial Economics, 09, 22-26.

[5] Li, M., Li, C., and Wei, Z. (2014). Does the Semi-mandatory Dividend Policy Create Value for Investors. Journal of Shanxi University of Finance and Economics, 36(6), 49-58.

[6] Lian, Y., Peng, F., and Su, Z. (2010). Financing Constraints and Liquidity Management Behavior. Journal of Finance Research, 10, 158-171.

[7] Liu, H., Wang, C. and Wu, L. (2014). Decision Rights Allocation, Earnings Management and Investment Efficiency. Economic Research Journal, 49(8), 93-106.

[8] Liu, R., Mao, Y., and Kang, Yankun. (2020). Deregulation, Market Vitality and Tourism Economy Development. Economic Research Journal, 55(01), 115-131.

[9] Lu, T., and Zhang, D. (2014). Financing Needs, Financing Constraints and Earning Management. Accounting Research, 01, 35-41.

[10] Lu, X., Zhen, Y., and Li, J. (2013). Research on the Impact of Financing Constraints on Corporate R\&D Investment. Accounting Research, 05, 51-58.

[11] Lu, Z., Wang, C., and Wang, P. (2010). Influencing Factors and Economic Consequences of Radical Dividend Policy. Journal of Finance Research, 06, 162-174.

[12] Luo, J., Huang, Z., and Zhu, J. (2017). Influence of Independent Directors' Geographic Distance on Corporate Agency Costs. China Industrial Economics, 08, 100-119.

[13] Martins, T.C., and Novaes, W. (2012). Mandatory dividend rules: Do they make it harder for firms to invest? Journal of Corporate Finance, 18(4), 953967.

[14] Porta, R.L., LDS, F., Shleifer, A., and Vishny, R.W. (2000). Agency Problems and Dividend Policies around the World. The Journal of Finance, 55(1), 1-33.

[15] Qu, W., Xie, Y., and Ye, Y. (2011). Information Asymmetry and InvestmentCash Flow Sensitivity. Economic Research Journal, 46(06), 105-117.

[16] Richardson, S. (2006). Over-investment of free cash flow. Review of Accounting Studies, 11(2-3), 159-189.

[17] Shleifer, A., and Vishny, R.W. (1997). A Survey of Corporate Governance. The Journal of Finance, 52(2), 737-783. 
[18] Wang, B., Mo, Q., and Qian, H. (2020). The Diffusion Models and Effects of the Local Environmental Policy Innovation. China Industrial Economics, 08, 99-117.

[19] Wang, C., and Guo, Y. (2021). Semi-Mandatory Dividend Policy and Cost of Equity. Journal of Finance Research, 08, 172-189.

[20] Wang, Z., and Zhang, W. (2012). Financial Flexibility and Refinancing of Listed Companies Research on Option and Dividend Catering Strategy. Management World, 07, 151-163.

[21] Wei, Z., Li, C., Wu, Y., and Huang, J. (2017). The Semi-mandatory Dividend Rules, Refinancing Motivation and Classical Dividend Theories. Accounting Research, 07, 55-61.

[22] Wei, Z., Li, M., and Li, C. (2014). The Semi-mandatory Dividend Rules and Dividend Behaviors of Chinese Listed Firms. Economic Research Journal, 49(6), 100-114.

[23] Welker, M., Ye K., and Zhang, N. (2017). (Un)intended Consequences of a Mandatory Dividend Payout Regulation for Earnings Management: Evidence From a Natural Experiment. Journal of Accounting, Auditing \& Finance, 32(4), 510-535.

[24] Xiong, J., and Su, D. (2014). Stock Liquidity and Capital Allocation Efficiency. Accounting Research, 11, 54-60.

[25] Yao, L., Chen, X., Zhou, Y., and Chen, X. (2020). Managerial Ability and Investment Efficiency. Accounting Research, 04, 100-118.

[26] You, J., and Li, B. (2007). Information Transparency and the Efficiency of Corporate Governance. Nankai Business Review, 10(4), 80-85. 